\title{
A Tale of Convergence? Discrimination based on Sexual Orientation in Regional Human Rights Bodies and the Human Rights Committee
}

\author{
Elena Abrusci \\ PhD Candidate at the School of Law, University of Nottingham, United \\ Kingdom \\ Elena.Abrusci@nottingham.ac.uk
}

The ICCPR and the regional human rights conventions do not explicitly prohibit discrimination based on sexual orientation, or provide the right to marry and have a family for same-sex couples, thus leaving an open margin of interpretation to their judicial and quasi-judicial enforcement bodies. However, regional courts and the Human Rights Committee (HRC) jurisprudence seems to have followed a path of convergence rather than fragmentation. This article will analyse the case-law of the regional judicial bodies and of the HRC on the matter through the lens of the prohibition of discrimination, assessing how such convergence has been reached and evaluating its nature. The analysis will reveal that beneath a seeming trend of convergence in the case outcomes, there are signs of a strong point of divergence and many threats of future fragmentation. In particular, there is a deep contrast between the European and the Inter-American Court of Human Rights in terms of prohibited discrimination based on sexual orientation. Moreover, the convergence reached among regional human rights bodies and the HRC hides vague and highly debated concepts and definitions on sensitive topics like marriage and adoption.

Keywords: Sexual Orientation Rights, Regional Human Rights Systems, Discrimination

\section{Introduction}


People face human rights abuses due to their sexual orientation everywhere in the world. The debate on the extent and interpretation of sexual orientation rights is particularly intense due to the strong relevance of cultural, social and religious concerns. ${ }^{1}$

The International Covenant on Civil and Political Rights (ICCPR) and the regional human rights conventions do not explicitly prohibit discrimination based on sexual orientation, or establish the right to marry and have a family for same-sex couples, thus leaving an open margin of interpretation to their judicial and quasi- judicial enforcement bodies. ${ }^{2}$ However, regional courts and the UN Human Rights Committee (HRC) seem to have followed, at least on the surface, the path of convergence rather than fragmentation. ${ }^{3}$ This convergence has been identified for the lack of obvious fragmentation, because there are no two cases based on comparable facts where these bodies have rendered judgments with contrasting outcomes. Indeed, the term fragmentation defines the phenomenon that arises when two courts (or quasi-judicial bodies) seized of the same (or similar) matter render contrasting judgments. ${ }^{4}$

The debate on fragmentation and convergence in international human rights law (IHRL) is still an ongoing matter of discussion. After some initial concerns that judicial

\footnotetext{
${ }^{1}$ Ignacio Saiz, 'Bracketing Sexuality: Human Rights and Sexual Orientation: A Decade of Development and Denial at the UN' (2004) 7 Health and Human Rights 48; Holning Lau, 'Sexual Orientation: Testing the Universality of International Human Rights Law' (2004) 71 The University of Chicago Law Review 1689; Amy Adamczyk and Cassady Pitt, 'Shaping Attitudes about Homosexuality: The Role of Religion and Cultural Context' (2009) 38 Social Science Research 338; Darren E Sherkat and others, 'Religion, Politics, and Support for Same-Sex Marriage in the United States, 1988-2008' (2011) 40 Social Science Research 167.

${ }^{2}$ International Covenant on Civil and Political Rights (ICCPR) (New York, 16 December 1966) 999 UNTS 171 and 1057 UNTS 407

3 Jack Donnelly, 'Non-Discrimination and Sexual Orientation: Making a Place for Sexual Minorities in the Global Human Rights Regime' in Peter Baehr, Cees Flinterman and Mignon Senders (eds), Innovation and Inspiration: Fifty Years of the Universal Declaration of Human Rights (Royal Netherlands Academy of Arts and Sciences 1999); Michael O'Flaherty and John Fisher, 'Sexual Orientation, Gender Identity and International Human Rights Law: Contextualising the Yogyakarta Principles' (2008) 8 Human Rights Law Review 207; Lau (n 1).

${ }^{4}$ Philippa Webb, International Judicial Integration and Fragmentation (OUP 2013).
} 
fragmentation was spreading within IHRL, commentators now tend to agree on the fact that regional and international human rights bodies have adopted a path of convergence and harmonisation of their case-law rather than fragmentation. ${ }^{5}$ Nevertheless, sometimes this convergence is only temporary and fragile, merely based on the impossibility of a comparison due to the lack of similar cases before different bodies. Judicial fragmentation may have particularly negative consequences for the human rights bodies, the potential victims and for the whole IHRL system of protection. ${ }^{6}$ For instance, it may threat the unity, coherence and consistency of the human rights legal order by challenging the principle of universality or it may question the legitimacy of human rights judicial and quasi-judicial bodies. On the other hand, it should also be acknowledged that fragmentation may sometimes produce positive outcomes, such as the progressive development of international human rights law, capable of answering to the changing needs of society. ${ }^{7}$ Therefore, a careful analysis of existing or highly probable situations of fragmentation is recommended, assessing the potential outcomes and impact to better respond to the eventual negative consequences of fragmentation.

In light of the above, this article aims at assessing and evaluating the nature of the convergence between regional systems and the HRC on sexual orientation rights, identifying the possible hints of fragmentation. Several scholars have explored the

\footnotetext{
${ }^{5}$ Marjan Ajevski, Fragmentation in International Human Rights Law: Beyond Conflict of Law (Routledge 2015); Carla Buckley, Alice Donald and Philip Leach (eds), Toward Convergence in International Human Rights Law: Approaches of Regional and International Systems (Brill/Nijhoff 2016).

${ }^{6}$ Pierre-Marie Dupuy, 'The Danger of Fragmentation or Unification of the International Legal System and the International Court of Justice' (1999) 31 NYU Journal of International Law and Politics 791; Webb (n 4); Ajevski (n 5); Georges Abi-Saab, 'Fragmentation or Unification: Some Concluding Remarks' (1999) 31 International Law and Politics 919.

${ }^{7}$ Anne-Charlotte Martineau, 'The Rhetoric of Fragmentation: Fear and Faith in International Law' (2009) 22 Leiden Journal of International Law 1; Yuval Shani, 'International Human Rights Bodies and the Little-Realized Threat of Fragmentation' (2016) Hebrew University of Jerusalem Legal Studies Research Paper Series No. 16-06.
} 
protection granted to sexual minorities and lesbian, gay, bisexual and transgender (LGBT) communities by international human rights law, but they have limited their analysis to one or two jurisdictions. ${ }^{8}$ This article departs from the existing literature and adopts a holistic view on the matter, taking into consideration all the main human rights regional systems and the UN Human Rights Committee. In line with the most recent contribution of Frans Viljoen, ${ }^{9}$ this study will use a comparative method focusing on the case-law (or the reasons for the lack of it) of the three main regional human rights systems, the European, the Inter-American and the African system, as well as the HRC. The study will deal with the prohibition of discrimination based on sexual orientation and will examine the specific substantive rights, whose enjoyment is often restricted to same-sex couples, through the lens of discrimination. Indeed, as a key right that regulates the enjoyment and protection of any other rights, the prohibition of discrimination has always been invoked when addressing sexual orientation rights violations. Considering the extremely low number of cases on the matter brought before the African Commission, the Inter-American Court and the HRC, all the cases related to sexual orientation before these three bodies will be examined. However, due to the high number of cases brought before the European Court of Human Rights (ECtHR) on matters of sexual orientation, only the most relevant cases have been selected for the purposes of this study.

\footnotetext{
${ }^{8}$ O'Flaherty and Fisher (n 3); Donnelly (n 3); Saiz (n 1); Lau (n 1); James D Wilets, 'International Human Rights Law and Sexual Orientation' (1994) 18 Hastings International and Comparative Law Review 731; John M Finnis, 'Law, Morality and "Sexual Orientation"” (1994) 69 Notre Dame Law Review; Douglas Sanders, 'Human Rights and Sexual Orientation in International Law' (2002) 25 International Journal of Public Administration 13; Emma Mittelstaedt, 'Safeguarding the Rights of Sexual Minorities: The Incremental and Legal Approaches to Enforcing International Human Rights Obligations' (2008) 9 Chicago Journal of International Law 353.

${ }^{9}$ Frans Viljoen, 'Minority Sexual Orientation as a Challenge to the Harmonised Interpretation of International Human Rights Law' in Carla M Buckley, Alice Donald and Philip Leach (eds), Toward Convergence in International Human Rights Law (Brill/Nijhoff 2016).
} 
Following this analysis, the article will conclude that it is possible to identify some elements that may lead to a potential fragmentation between some of the regional and international bodies. This is particularly true for the understanding of some key notions such as what constitutes a discriminatory treatment, what constitutes a family and whether, in general, there should be a sharp prohibition of discrimination based on sexual orientation.

\section{The Prohibition of Discrimination on the Ground of Sexual Orientation}

Human rights violations related to sexual orientation derive from a discriminatory treatment that prevents or diminishes the enjoyment of individuals' rights on the basis of their sexual orientation. ${ }^{10}$ Discrimination based on sexual orientation could be defined as 'treating differently, without an objective and reasonable justification, persons in analogous, or relevantly similar, situations" due to their sexual orientation. ${ }^{11}$ Similarly, an equal treatment that has an adverse or disparate impact on people according to their sexual orientation still amounts to discrimination, although indirectly. While the facts of the abuse may raise claims under other substantial rights, the principle of nondiscrimination is always decisive in regulating such issues. Social life is full of many kinds of legitimate differences in treatment, aiming at protecting and safeguarding some categories of people and ensuring the enjoyment of their rights. However, if this different treatment becomes public and invidious, depriving certain groups from the legitimate enjoyment of their rights, then it is prohibited by international human rights law. ${ }^{12}$

\footnotetext{
${ }^{10}$ Sandra Fredman, Discrimination Law (OUP 2011) 86-93.

${ }^{11}$ Kiyutin v Russia, Application No. 2700/10, (ECtHR, 10 March 2011), 59.

${ }^{12}$ Fredman, Discrimination Law (n 10).
} 
All core human rights instruments, from the Universal Declaration and the ICCPR at the international level to the regional human rights Charters and Conventions, do not envisage 'sexual orientation' as a prohibited ground for discrimination, leaving wide margin of interpretation to the adjudicatory bodies. However, regional bodies and the Human Rights Committee did somehow converge in filling this gap and providing judicial protection in case of discrimination based on sexual orientation. Sexual orientation does not have a universally agreed upon definition in legal documents, but one may consider it as 'each person's capacity for profound emotional, affectional and sexual attraction to, and intimate and sexual relations with, individuals of a different gender or the same gender or more than one gender". ${ }^{13}$ The present article will adopt this expression, and it can be understood to include all cases dealing with alleged violations of human rights on the basis of the individual's homosexuality, heterosexuality or bisexuality.

States have adopted completely different approaches to sexual orientation rights, from criminalising any homosexual activity to granting same-sex couples all the rights enjoyed by heterosexual couples. The signing of the Yogyakarta Principles on the Application of International Human Rights Law in relation to Sexual Orientation and Gender Identity ${ }^{14}$ was an important step for identifying the international human rights obligations states should bear in relation to LGBT communities. ${ }^{15}$ In addition to the Yogyakarta Principles, regional and international bodies made several efforts to protect

${ }^{13}$ Yogyakarta Principles-Principles on the Application of International Human Rights Law in relation to Sexual Orientation and Gender Identity, March 2007, available at http://www.yogyakartaprinciples.org/, accessed 11 ${ }^{\text {th }}$ June 2017 (hereinafter Yogyakarta Principle), Preamble.

${ }^{14}$ ibid.

${ }^{15}$ O'Flaherty and Fisher (n 3). The acronym LGBT stands for 'Lesbian, Gay, Bisexual and Transgender" but will be used in this article with a particular reference to lesbians, gays and bisexuals who are the most discriminated individuals for their sexual orientation. 
people against discrimination based on sexual orientation. However, the principles remain at a soft-law level and their impact on the judicial application of international and domestic legislations is limited ${ }^{16}$, thus not establishing legal obligations upon member states. For instance, in 2011, the UN Human Rights Council adopted the first resolution on sexual orientation, being the first UN body to take an official position on the issue, ${ }^{17}$ followed by a dedicated report of the Office of the High Commissioner for Human Rights. ${ }^{18}$ Within the Council of Europe framework, where countries like Russia and Moldova still condemn homosexuality, worth recalling is the 1981 Parliamentary Assembly Recommendation No.924, which calls upon states to decriminalise homosexual acts ${ }^{19}$, and the 2010 recommendation of the Committee of Ministers, urging states to adopt and effectively implement legislative and other measures to prevent discrimination based on sexual orientation. ${ }^{20}$ In the Americas, the OAS General Assembly adopted from 2008 to 2012 a series of resolutions on human rights and sexual orientation, requesting states to incrementally protect the rights of sexual minorities and fight against discrimination based on sexual orientation. ${ }^{21}$ Moreover, in 2013, the InterAmerican Commission decided to establish a Rapporteurship on LGBTI rights to further strengthen the regional promotion and protection of human rights. Finally, within the

\footnotetext{
${ }^{16}$ Michael O'Flaherty, 'The Yogyakarta Principles at Ten' (2015) 33 Nordic Journal of Human Rights 280.

${ }^{17}$ UN HRC Resolution on Human rights, sexual orientation and gender identity, HRC/RES/17/19, 17 June 2011

${ }^{18}$ Discriminatory laws and practices and acts of violence against individuals based on their sexual orientation and gender identity, A/HRC/19/41, 14 July 2011.

${ }^{19}$ Recommendation of the Parliamentary Assembly on Discrimination against homosexuals No. 924, Doc. 4755, 1 October 1981.

${ }^{20}$ Recommendation of the Committee of Ministers to member states on measures to combat discrimination on ground of sexual orientation or gender identity, CM/Rec(2010)5, 31 March 2010.

${ }^{21}$ Human Rights, Sexual Orientation and Gender Identity, OAS AG/RES 2435(XXXVIII-O/080, 3 June 2008; OAS AG/RES 2504(XXXXIX-O/09), 4 June 2009, OAS AG/RES 2600(XL-O/10), 8 June 2010; OAS AG/RES 2653(XLI-O/11), 7 June 2011; OAS AG/RES 2721(XLII-O/12), 4 June 2012.
} 
African system sexual orientation rights has been more controversial issue. The Organisation of African Unity or the African Union have not addressed the matter of sexual orientation yet. However, the African Commission adopted in 2014 a resolution On Protection against Violence and other Human Rights Violations against Persons on the Basis of their Real or Imputed Sexual Orientation or Gender Identity, mentioning for the first time sexual orientation issues.

\section{The International Covenant on Civil and Political Rights and the Human Rights Committee}

Article 2(1) of the ICCPR reads:

[e]ach State Party [...]undertakes to respect and to ensure to all individuals $[\ldots]$ the rights recognized in the present Covenant, without distinction of any kind, such as race, colour, sex, language, religion, political or other opinion, national or social origin, property, birth or other status. ${ }^{22}$

Similarly, article 26 provides that:

[a]ll persons are equal before the law and are entitled without any discrimination to the equal protection of the law. In this respect, the law shall prohibit any discrimination and guarantee to all persons equal and effective protection against discrimination on any ground such as race, colour, sex, language, religion, political or other opinion, national or social origin, property, birth or other status. ${ }^{23}$

In interpreting the letter of these articles applied to cases of discrimination based on sexual orientation, the Human Rights Committee took a clear stance in filling the

\footnotetext{
22 ICCPR, art 2.

${ }^{23} \mathrm{ibid}$, art 26.
} 
normative gap. In Toonen $v$ Australia, ${ }^{24}$ the first case on the issue brought before the HRC in $1994,{ }^{25}$ the Committee unanimously concluded that the criminalisation of same-sex relations violated the principle of non-discrimination. Indeed, the HRC noted that 'the reference to "sex" in articles 2(1) and 26 is to be taken as including sexual orientation'. ${ }^{26}$

From this moment, the HRC has persistently held that discrimination based on sexual orientation should always be considered as 'a suspect category in terms of enjoyment of Covenant rights and, more generally, for equality before and equal protection of the law'. ${ }^{27}$

However, in the subsequent cases, the Committee relied on the more general notion that 'everyone' or 'all human beings' should enjoy the same rights. ${ }^{28}$ Reading 'sex' as including also 'sexual orientation' as ground of discrimination has positive and negative aspects. On the one hand, considering the importance of the 'sex' category in the Covenant and in any anti-discrimination provisions, this radical and provocative ${ }^{29}$ interpretation elevates the status of discrimination based on sexual orientation, and potentially extends the prohibition of discrimination to all legal instruments where there is a stated prohibition of discrimination based on sex. Moreover, as American scholars have largely discussed, considering discrimination based on sexual orientation as falling under discrimination based on sex is particularly correct since the former is just another way to maintain a hierarchy between gender and gender roles. ${ }^{30}$ On the other hand, this

\footnotetext{
${ }^{24}$ Toonen v Australia, Communication No.488/1992, (HRC, 31 March 1994).

${ }^{25}$ Hertzberg and Others $v$ Finland, Communication No. 61/1979, (HRC, 2 April 1982). While tackling the issue of sexual orientation, the complaint focused on the violation of freedom of expression.

${ }^{26}$ Toonen (n 24) 8.7.

${ }^{27}$ Michael O'Flaherty and John Fisher (n 3).

28 Joslin et al.v New Zealand, Communication No.902/1999,(HRC,17 July 2002).

${ }^{29}$ Jack Donnelly (n 3) 21.

${ }^{30}$ Andrew Koppelmann, 'Why Discrimination Against Lesbians and Gay Men Is Sex Discrimination' (1994) 69 New York University Law Review 197; Sylvia Law, 'Homosexuality and the Social Meaning of Gender' (1998) Wisconsin Law Review 187.
} 
assimilation may be considered incorrect because the drafters of the ICCPR intended the prohibition on sex discrimination to address the subordination of women; treating sexual orientation discrimination as sex discrimination conflicts with this original intent. Moreover, it does not take into consideration the differences between the suffering of women and sexual minorities. ${ }^{31}$

All the cases after Toonen adopt the same approach of condemnation of discrimination based on sexual orientation, though with some differences due to the facts of the case and the nature of the other rights claims.

In Young $v$ Australia ${ }^{32}$ and $X v$ Colombia ${ }^{33}$ the Committee found discrimination in the distinction between same-sex partners excluded from pension benefits that were otherwise granted to unmarried heterosexual partners. In both cases, the Committee found that the states failed to prove that the difference in treatment was reasonable and objective, thus violating article $26 .{ }^{34}$ However, in $X . v$ Colombia, a dissenting opinion of two members of the HRC pointed out that 'a couple of the same sex does not constitute a family within the meaning of the Covenant and cannot claim benefits that are based on a conception of the family comprising individuals of different sex' ${ }^{35}$ This strong position, even if marginal and representative of the opinion of only two members, is a significant step backward in the development of a progressive concept of family, key for the enjoyment of sexual orientation rights. Indeed, it showed that even on the basic notion of family there is no unanimity within the HRC on whether it should be inclusive of homosexual couples.

\footnotetext{
${ }^{31}$ Jack Donnelly (n 3) 21.

${ }^{32}$ Young v Australia, Communication No. 941/2000 (HRC, 6 August 2003).

${ }^{33}$ X v Colombia, Communication No. 1361/2005 (HRC, 30 March 2007).

${ }^{34}$ Ibid, 7.2 and Young (n 32), 10.4.

35 ibid, dissenting opinion.
} 
Differently, in Joslin v New Zealand, ${ }^{36}$ the HRC did not find any violation of article 2 or 26 in the case of the denial of a marriage licence to a same-sex couple. The right to marry is protected, under the ICCPR, by article 23: '[...] The right of men and women of marriageable age to marry and to found a family shall be recognized' ${ }^{37}$

The letter of the article seems quite strict on who can enter in a marriage and, so far, the HRC has not extended its interpretation to same-sex couples. In Joslin v New Zealand $^{38}$, the Committee briefly concluded that the ICCPR does not protect the right to marry for same-sex couple, since the use of the terminology 'men and women' in article 23, rather than the gender-neutral terminology used elsewhere in the ICCPR (like 'everyone' or 'all persons'), 'has been consistently and uniformly understood as indicating that [...]marriage [is] only the union between a man and a woman'. ${ }^{39}$ This categorical assertion clashes with the Committee's position in its General Comments that 'marriage' and 'the family' are to be understood as continuously evolving concepts that apply to a diversity of arrangements across cultures. ${ }^{40}$

However, an individual concurring opinion of two members of the HRC left the door open to a different interpretation, by affirming that the Committee's

[c]onclusion should not be read as a general statement that differential treatment between married couples and same-sex couples not allowed under the law to marry would never amount to a violation of Article 26. On the contrary, the Committee's jurisprudence supports the position that such differentiation may very well, depending on the circumstances of a

\footnotetext{
${ }^{36}$ Joslin (n 28).

${ }^{37}$ ICCPR, art 23.

${ }^{38}$ Joslin (n 28).

39 ibid, 8.2.

${ }^{40}$ UN Human Rights Committee (HRC), CCPR General Comment No. 19: Article 23, 27 July 1990, 2-4; UN Human Rights Committee (HRC), CCPR General Comment No. 28: Article 3, 29 March 2000, 23-27; Ignacio Saiz (n 1).
} 
concrete case, amount to prohibited discrimination. ${ }^{41}$

\section{The European System}

The European Court of Human Rights has considered issues related to discrimination based on sexual orientation in several cases. Article 14 of the European Convention on Human Rights (ECHR), in line with ICCPR article 26, states that [t]he enjoyment of the rights and freedoms $[\ldots]$ shall be secured without discrimination on any ground such as sex, race, colour, language, religion, political or other opinion, national or social origin, association with a national minority, property, birth or other status. ${ }^{42}$

The abundant case-law on sexual orientation rights is helpful in understanding the approach of the ECtHR toward discrimination based on sexual orientation. The ECtHR, in contrast to the HRC, has never found it necessary to discuss whether discrimination based on sexual orientation derives from the grounds of 'sex' or 'other status' or otherwise. $^{43}$

For instance, in Salgueiro da Silva Mouta v Portugal, the ECtHR stated that discrimination on the basis of sexual orientation was not acceptable under the ECHR. ${ }^{44}$ In L. and V. v Austria and S. v Austria ${ }^{45}$, it considered the differentiation of the age of consent for heterosexual or homosexual relations discriminatory, establishing that ' $[\mathrm{j}] \mathrm{ust}$

\footnotetext{
${ }^{41}$ Joslin (n 28), Individual opinion of Committee members Mr. Rajsoomer Lallah and Mr. Martin Scheinin.

${ }^{42}$ Council of Europe, Convention for the Protection of Human Rights and Fundamental Freedoms (ECHR) 1950, art 14.

${ }^{43}$ Sutherland v United Kingdom, Application no 25186/94, (ECtHR, 1 July 1997).

${ }^{44}$ Salgueiro da Silva Mouta v Portugal, Application No. 33290/96 (ECtHR, 21 December 1999), 36.

${ }^{45}$ L. and V. v Austria, Applications no 39392/98 and 39829/98 (ECtHR, 9 January 2003).
} 
like differences based on sex[...]differences based on sexual orientation require particularly serious reasons by way of justification ${ }^{46}$ for the purpose of article 14 .

A more detailed analysis of the case-law of the ECtHR could improve our understanding of the approach of the ECtHR. Due to the huge number of cases rendered on the matter, I will analyse three categories in particular, namely the right to marriage or to other relationship registration, parental authority and adoption and social protection.

\subsection{Right to marriage or other relationship registration}

In its landmark cases on the right to marry for same-sex couples, the ECtHR adopted a cautious approach in extending such a right beyond the traditional conception of marriage. For instance, in Christine Goodwin v United Kingdom, ${ }^{47}$ it ruled that the right to marry is not limited to persons who are biologically of the opposite sex, opening up the possibility of an extension to same-sex marriage. However, when deciding cases specifically concerning same-sex marriage, the ECtHR adopted a different stance.

The first case on the matter was Schalk and Kopf v. Austria, ${ }^{48}$ concerning the denial of permission to marry for a homosexual couple. The applicants claimed that they suffered from violation of their right to marry in conjunction with the prohibition of nondiscrimination based on sexual orientation. In examining the case, the ECtHR recognised an evolution of social attitudes toward same-sex couples in many member states considering cohabiting same-sex couples living in a stable de facto relationship as falling within the notion of family life. ${ }^{49}$ Nonetheless, it adopted a similar approach as the HRC in observing that article 12 of the ECHR establishes the right to marry between 'a man

\footnotetext{
${ }^{46} \mathrm{ibid} 37$. The Austrian legislation provided that for heterosexual relations the age of consent was 14 while for homosexual relationships was 18 .

${ }^{47}$ Christine Goodwin v the United Kingdom, Application No. 28957/95 (ECtHR, 11 July 2002).

${ }^{48}$ Schalk and Kopf v. Austria, Application no. 30141/04 (ECtHR, 22 November 2010).

${ }^{49}$ ibid, 93-95; David J Harris and others, Law of the European Convention on Human Rights (OUP 2014) 804.
} 
and a woman' and does not provide such right for 'everyone' or 'all human beings'. The ECtHR argued that marriage is an institution deeply rooted in local societies and its regulation should be left to the single member states. Moreover, the ECtHR noticed that there was no European consensus on gay marriage, at the time only 6 out of 47 member states had adopted domestic legislation allowing for gay marriage. In light of this, while recognising the possibility of interpreting article 12 as allowing same-sex marriage, the ECtHR concluded that there was no violation of the right to marry, since article 12 does not impose any obligation upon member states to provide the right to marry for same-sex couples. $^{50}$

The ECtHR adopted the same reasoning and conclusion was in the only other case on the issue, Chapin and Charpentier v France ${ }^{51}$, decided in 2016. Here, it confirmed its position and considered that the regional consensus on marriage for same-sex couples had not yet been reached, even if the number of member states who adopted national legislation allowing same-sex marriage had increased to 11 .

Lastly, in 2012, Miss Orlandi and others ${ }^{52}$ filed a complaint against Italy for the refusal of marriage recognition of four Italian same-sex couples. The ECtHR is still considering the case and it will be interesting to see whether it will change its approach now that the number of member states that recognise same-sex marriage is increasing. ${ }^{53}$

Before concluding this section, it is worth mentioning the landmark case of the Strasbourg court on recognition of same-sex partnerships, Oliari and others $v$ Italy. ${ }^{54}$ When it comes to same-sex partnerships that do not amount to marriage, the approach of

\footnotetext{
${ }^{50}$ Schalk and $\operatorname{Kopf}$ (n 48) 57-60.

${ }^{51}$ Chapin and Charpentier v France, Application No. 40183/07 (ECtHR, 9 June 2016).

${ }^{52}$ Orlandi and Others $v$ Italy, Application No. 26431/12, 26742/12, 44057/12 and 60088/12.

${ }^{53}$ Data available on the website of ILGA Europe at http://old.ilgaeurope.org/home/guide_europe/country_by_country, last accessed 22 ${ }^{\text {nd }}$ February 2017.

${ }^{54}$ Oliari and Others $v$ Italy, Application No. 18766/11 and 36030/11(ECtHR, 21 July 2015)
} 
the ECtHR has been far more protective for the applicants' rights. The case concerned six Italian male citizens claiming that the absence of any legal provision allowing them to marry or to access to any form of civil union was amounting to discrimination based on their sexual orientation together with violation of their right to family and private life. The ECtHR held that Italy did not respect the applicants' private and family life by denying them the opportunity 'to enter into a civil union or registered partnership'. ${ }^{55}$ Moreover, it considered that Italy had overstepped its margin of appreciation and that the lack of a legal framework recognising and protecting the applicants' relationship violated article $8 .{ }^{56}$ However, as for the right to marry, the ECtHR remained very cautious recalling its previous ruling in Shalk and Kopf and allowing states to enjoy a wider margin of appreciation. ${ }^{57}$ This judgment represents a huge victory for LGBT rights because it establishes the right for same-sex couple to enter into civil partnerships, significantly reducing the state's margin of appreciation on this matter. However, the ECtHR did not consider the alleged violation under article 14, thus not assessing whether Italy was treating the applicants in a discriminatory way by denying them the possibility to enter into a marriage or civil partnership. Moreover, it failed to make any progress in relation to the rights to marry for homosexual couples, when it emphasised that homosexual couples only have a right to enter in civil partnership and not to get married. ${ }^{58}$

\footnotetext{
55 ibid, 164.

56 ibid, 185.

${ }^{57}$ ibid, 189-194.

${ }^{58}$ Eduardo Savarese, "In margine al caso Oliari: ovvero di come il limbo italiano delle coppie omosessuali abbia violato gli obblighi positive dell'art. 8 CEDU" (2015) 3 Diritti Umani e Diritto Internazionale; Sabrina Ragone and Valentina Volpe, "An Emerging Right to a "Gay" Family Life? The Case Oliari v. Italy in a Comparative Perspective’ (2016) 17 German Law Journal.
} 


\subsection{Parental authority and adoption}

The first case where the ECtHR found a violation of article 14 based on sexual orientation was in 1999, in Salgueiro da Silva Mouta v Portugal. ${ }^{59}$ Here, the ECtHR considered that the denial of parental responsibility on the ground of the father's sexual orientation was prohibited by the Convention. The ECtHR openly contested the position of the Portuguese Court that awarded exclusive parental responsibility to the mother on the assumption that homosexuality constitutes an abnormality and children should grow up in normal and traditional Portuguese families. ${ }^{60}$ According to the ECtHR, the Convention does not allow a distinction between a 'normal' and an 'abnormal' family and doing so on the basis of the sexual orientation of a parent amounts to a violation of the right to respect of family life in conjunction with the prohibition of discrimination based on sexual orientation. ${ }^{61}$

Worth mentioning in this analysis is also E.B. $v$ France $^{62}$, a case concerning the complaint of a woman who saw her adoption request denied on the ground of her lifestyle as a lesbian living with another woman. The ECtHR here found a violation of article 14 in conjunction with article 8 because the sexual orientation of the applicant was the determining factor in refusing her request for adoption, whereas heterosexual single individuals were allowed to adopt a child. To this end, it specified that the Convention does not provide the right to 'found a family' or to 'adopt' but it protects the family and private life, including the possibility to get an adoption. Moreover, in order to constitute a violation under article 14, the ECtHR underlined that 'the reasons advanced for such a

\footnotetext{
${ }^{59}$ Salgueiro da Silva Mouta (n 44).

60 ibid 34.

61 ibid 35-36.

${ }^{62}$ E.B. v France, Application No. 43546/02 (ECtHR, 22 January 2008).
} 
difference in treatment [should be] based solely on considerations regarding the applicant's sexual orientation.' ${ }^{63}$

On the contrary, in Gas and Dubois v. France ${ }^{64}$, the ECtHR found no discrimination based on sexual orientation when dealing with the complaint of two cohabiting women for the refusal to Miss Gas to adopt the natural son of Miss Dubois. They claimed that this decision infringed their right to private and family life in a discriminatory manner. The ECtHR found no violation of article 8 in conjunction with article 14 , considering the impossibility of comparing the situation of the applicants with that of heterosexual married couples. ${ }^{65}$ Indeed, domestic legislation prohibited a simple adoption order for unmarried heterosexual couples in a civil relationship, thus not creating any discrimination with same-sex couples in the same civil situation. In response to the applicants' argument that heterosexual couples do have the possibility of marriage if they want to adopt while same-sex couples do not, the ECtHR simply restated its position in Schalk and Kopf $v$ Austria, recalling that there is no right to marry and that member states should enjoy a wide margin of appreciation on this matter. ${ }^{66}$

Similar reasoning, focused on the impossibility to compare the situation of homosexual couples unable to marry and married heterosexual couples, was applied in $X$ and Others $v$ Austria. ${ }^{67}$ The case concerned the refusal to grant one partner the right to adopt the son of the other partner while living in a stable homosexual relationship, claiming a violation of article 8 and to be a victim of discrimination on the basis of their sexual orientation considering that adoption was granted to both married and unmarried

\footnotetext{
${ }^{63}$ ibid 93.

${ }^{64}$ Gas and Dubois v France, Application No. 25951/07 (ECtHR, 15 June 2012).

65 ibid 68-69.

66 ibid 66-68, 71 and 73.

${ }^{67}$ X and Others $v$ Austria, Application No. 19010/07 (ECtHR, 19 February 2013).
} 
heterosexual couples. The ECtHR, in a highly debated judgment, held that there was no violation of article 14 in conjunction to article 8 when the situation of the applicants was compared to heterosexual married people. ${ }^{68}$ However, voting ten to seven, it found a violation of article 14 in conjunction with article 8 when the applicants were compared to unmarried heterosexual couples, who are indeed granted the possibility of step-child adoption. ${ }^{69}$ The ruling in favour of the applicant shows the willingness of the ECtHR to protect the rights of same-sex couples and aligns it to the case-law of other bodies. However, the fact that the decision was made with such a small majority means that there was a strong debate among the judges. Furthermore, this case showed that an issue that had seemingly been established in other cases, namely the prohibition of discrimination based solely on sexual orientation, was challenged when the issue of adoption and the rights of children were at stake.

\subsection{Social protection}

The case-law of the ECtHR on social protection for same-sex couples is particularly interesting, showing different approaches when interpreting and applying articles 8 and 14. In 2001, the ECtHR ruled on Mata Estevez $v$ Spain, ${ }^{70}$ on the denial of a survivor's pension to the de facto homosexual partners considered as a discriminatory act if compared to the treatment reserved to married heterosexual couples. It considered the application inadmissible and manifestly ill-founded since the eligibility criteria for the survivor's pension that excluded homosexual couples were pursuing the legitimate aim of protecting the family based on marriage bonds. The difference of treatment between

\footnotetext{
68 ibid 105-110.

69 ibid 153.

${ }^{70}$ Mata Estevez v Spain, Application No. 56501/00 (ECtHR, 10 May 2001).
} 
same-sex and heterosexual couple did not amount to discrimination, but rather fell within the state's margin of appreciation. ${ }^{71}$

The same position was reiterated in June 2016 when the ECtHR ruled on the very similar case Aldeguer Tomás v. Spain. ${ }^{72}$ The facts of the case were exactly the same as the previous case, with the only difference being the time frame. In 2005 Spain approved a law legalising same-sex marriage, thus removing any obstacles for a person to get the survivor's pension of his partner regardless of his or her sexual orientation. However, the ECtHR confirmed its approach, finding no discriminatory treatment based on sexual orientation. ${ }^{73}$ In line with its case-law on the right to marry, the ECtHR held that states should enjoy a certain margin of appreciation when it comes to the timing of the introduction of legislative changes in the field of legal recognition of same-sex couples and the exact status conferred to them, considering this an area of evolving rights with no established regional consensus. ${ }^{74}$

To the contrary, in all cases concerning the succession to a tenancy for the samesex partner of the deceased, ${ }^{75}$ the ECtHR found a violation of article 8 in conjunction with article 14 without granting the states any margin of appreciation. Similarly, in P.B. and J.S. $v$ Austria ${ }^{76}$, the ECtHR held that domestic legislations considering as 'dependants' only a close relative of the insured person or a cohabitee of the opposite sex were discriminatory on the basis of sexual orientation.

\footnotetext{
71 ibid (admissibility decision).

${ }^{72}$ Aldeguer Tomas v Spain, App no. 35214/09 (ECtHR, 14 June 2016).

73 ibid 91.

74 ibid 90.

75 Karner v Austria, Application No. $40016 / 98$ (ECtHR, 24 October 2003); Kozak v Poland, Application No. 13102/02 (ECtHR, 2 June 2010).

${ }^{76}$ P.B. and J.S. v Austria, Application No. 18984/02 (ECtHR, 22 July 2010).
} 


\section{The African System}

The African Charter on Human and People Rights contains a non-discrimination provision in line with other regional and international systems. Article 2 states that:

Every individual shall be entitled to the enjoyment of the rights and freedoms[...] without distinction of any kind such as race, ethnic group, colour, sex, language, religion, political or any other opinion, national and social origin, fortune, birth or any status. ${ }^{77}$

Little information is available on the applicability of this non-discrimination provision to sexual orientation cases, since the case-law on the matter is very scarce and neither the African Commission on Human and People's Rights (ACommHPR) nor the African Court on Human and People's Rights (ACtHPR) have issued any conclusion or judgment explicitly on discrimination based on sexual orientation. In light of that, we can only hypothetically conclude that discrimination based on sexual orientation in the African system should be generally prohibited and condemned, assuming that the African bodies will adopt the same approach of the HRC and the ECtHR when interpreting an almost identical provision to the one contained in the ICCPR and ECHR.

However, if we look at the cases brought before of the Commission, some of them can be useful to understand the Commission's approach. In 1994, Mr Courson brought a complaint against Zimbabwe claiming that the prohibition of sexual contacts between consenting adult homosexual men in private was a violation of his rights under the African Charter, including the right not to be discriminated on the basis of sexual orientation. ${ }^{78}$ The Commissioner acting as a rapporteur for the case openly declared that

\footnotetext{
${ }^{77}$ Organization of African Unity (OAU), African Charter on Human and Peoples' Rights ("Banjul Charter"), 27 June 1981, CAB/LEG/67/3 rev. 5, 21 I.L.M. 58 (1982), art 2.

${ }^{78}$ William A. Courson v Zimbabwe, Communication No. 136/94 (ACommHPR, withdrawn 22 March 1995).
} 
because of the deleterious nature of homosexuality, the Commission seizes the opportunity to make a pronouncement on it. Although homosexuality and lesbianism are gaining recognition in certain parts of the world, this is not the case in Africa. Homosexuality offends the African sense of dignity and morality and is inconsistent with positive African values. ${ }^{79}$

Not surprisingly, after such declaration, Mr Courson decided to withdraw the application and the Commission never ruled on the case.

In 2006, this strong stance against sexual orientation rights was overruled by the Commission's conclusions in Zimbabwe Human Rights NGO Forum v Zimbabwe ${ }^{80}$ Here, the Commission affirmed that the African Charter safeguards 'equality of treatment for individuals irrespective of [...] sexual orientation. ${ }^{81}$ However, this opinion was expressed obiter, as the case did not concern the issue of sexual orientation as such. Moreover, the recent Resolution 275 On Protection against Violence and other Human Rights Violations against Persons on the Basis of their Real or Imputed Sexual Orientation or Gender Identity, adopted in 2014, showed an increasing interest and concern towards the rights of LGBT people. ${ }^{82}$ Still, the resolution does not mention the prohibition of discrimination on the basis of sexual orientation, limiting its scope to the condemnation of violence against LGBT people.

According to some scholars, these few developments should be considered as the assurance of the favourable approach of the ACommHPR, and potentially the ACtHPR,

79 EA Ankumah, The African Commission on Human and Peoples' Rights: Practice and Procedures (Nijhoff, 1996) 174, as quoted in F Viljoen, International Human Rights Law in Africa (OUP, 02012) 265.

${ }^{80}$ Zimbabwe Human Rights NGO Forum v Zimbabwe, Comm. No 245/02 (ACommHPR, 15 May 2006).

81 ibid 169.

82 African Commission on Human and People's Rights, Resolution 275 On Protection against Violence and other Human Rights Violations against Persons on the Basis of their Real or Imputed Sexual Orientation or Gender Identity, 55 ${ }^{\text {th }}$ Ordinary Session 28 April-12 May 2014. 
toward the protection of LGBT people against discrimination based on their sexual orientation. ${ }^{83}$ However, this position appears quite optimistic and does not take into consideration that the ACommHPR has always adopted a circumstantial approach toward discrimination based on sexual orientation; it did recognise its prohibition under article 2, but only in one case that was decided on other bases. Moreover, the ACommHPR decided not to make any reference to it in Resolution 275. Moreover, it should be underlined that, in the African continent, thirty-one countries criminalise homosexual relationships, and four of them provide death penalty for such crime, and still the African Commission has not received yet any application from individuals denouncing discrimination based on sexual orientation after the failed Courson case in 1994.

\section{The Inter-American System}

The American Convention on Human Rights states in article 1 that all states parties should respect, ensure and protect the rights contained in the convention

$[w]$ ithout any discrimination for reasons of race, colour, sex, language, religion, political or other opinion, national or social origin, economic status, birth, or any other social condition. ${ }^{84}$

In line with the other human rights instruments, there is no explicit reference to sexual orientation and room for interpretation is left under the ground of 'sex' or the very broad 'any other social condition'.

\footnotetext{
${ }^{83}$ Frans Viljoen, 'The Relevance Of The Inter-American Human Rights System For Africa' (1999) 11 African Journal of International and Comparative Law; Annika Rudman, 'The Protection against Discrimination Based on Sexual Orientation under the African Human Rights System' (2015) 15 African Human Rights Law Journal 1.

${ }^{84}$ Organization of American States (OAS), American Convention on Human Rights, "Pact of San Jose", Costa Rica, 22 November 1969, art 1.
} 
The Inter-American Court addressed the issue of discrimination based on sexual orientation in two landmark cases: Atala Riffo and Daughters $v$ Chile $e^{85}$ and Angel Duque $v$ Colombia. ${ }^{86}$ In Atala Riffo $v$ Chile, the IACtHR dealt with the case of a lesbian woman who was denied the custody of her three daughters on the basis that her sexual orientation had adverse effects on them. It held that

$[w]$ hen interpreting the words "any other social condition" $[\ldots]$ it is always necessary to choose the alternative that is most favourable to the protection of the rights enshrined in said treaty, based on the principle of the rule most favourable to the human being. ${ }^{87}$

Recalling the case-law of the ECtHR and the HRC on the matter ${ }^{88}$, the IACtHR concluded that

[t]he sexual orientation of persons is a category protected by the Convention. Therefore, any regulation, act, or practice considered discriminatory based on a person's sexual orientation is prohibited. Consequently, no domestic regulation, decision, or practice, whether by state authorities or individuals, may diminish or restrict, in any way whatsoever, the rights of a person based on his or her sexual orientation. ${ }^{89}$

A crucial passage in the judgment shows the IACtHR's understanding of the notion of discrimination based on sexual orientation. Indeed, the Court held that for proving

\footnotetext{
${ }^{85}$ Atala Riffo and Daughters v Chile, (IACtHR, 24 February 2012).

${ }^{86}$ Angel Alberto Duque v Colombia (IACtHR, 26 February 2016).

${ }^{87}$ Atala Riffo (n 85) 84.

${ }^{88}$ ibid 87-89.

${ }^{89}$ ibid 91.
} 
[t]hat a distinction in treatment has occurred, it is not necessary that the decision in its entirety be based "fundamentally and solely" on the person's sexual orientation. It is sufficient to confirm that, to a certain extent, the person's sexual orientation was taken into account, either explicitly or implicitly, in adopting a specific decision. ${ }^{90}$

In stating such a position, the IACtHR explicitly referred to the following passage from the ECtHR's ruling in E.B. v France: ${ }^{91}$

[n]otwithstanding the precautions taken [...] to justify taking account the applicant's "lifestyle", the inescapable conclusion is that her sexual orientation was consistently at the centre of deliberations in her regard and omnipresent at every stage of the administrative and judicial proceedings. [...] The Court considers that the reference to the applicant's homosexuality was, if not explicit, at least implicit. The influence of the applicant's avowed homosexuality on the assessment of her application has been established and, having regard to the foregoing, was a decisive factor leading to the decision to refuse her authorization to adopt. ${ }^{92}$

This reference appears odd in at least two respects. First, it does not seem to be the correct paragraph to substantiate and explain what the Inter-American Court actually says. Indeed, the IACtHR was establishing a lower threshold than the ECtHR for the definition of a discriminatory treatment, which does not need to be fundamentally and solely based on sexual orientation but it is enough to prove that to a certain extent this ground, even

\footnotetext{
${ }^{90}$ ibid 94.

${ }^{91}$ E.B. (n 62).

92 ibid 88-89, emphasis added.
} 
implicitly, has been taken into account. The ECtHR, in the previous extract from E.B. $v$ France, was clearly expressing a different principle. While it is true that the ECtHR held that 'the reference to the applicant's homosexuality was, if not explicit, at least implicit', the Court actually acknowledged that the sexual orientation of the applicant was 'consistently at the centre of deliberations in her regard and omnipresent at every stage of the administrative and judicial proceedings' and that it 'was a decisive factor' in the decision of the domestic court. ${ }^{93}$ Therefore, it can not be concluded that the ECtHR in the aforementioned passage was agreeing with the IACtHR on the fact that a different treatment is discriminatory when is 'confirmed that, to a certain extent, the sexual orientation of the applicant has been taken into account either explicitly or implicitly. ${ }^{94}$

The second respect of peculiarity of this example of judicial borrowing is that the Inter-American Court is referring to paragraph 88-89 of the judgment of the ECtHR that can not be extrapolated from the context. Indeed, in paragraph 93, the ECtHR explicitly stated that 'if the reasons advanced for such a difference in treatment were based solely on considerations regarding the applicant's sexual orientation this would amount to discrimination under the Convention'. ${ }^{95}$ The ECtHR made clear that the sexual orientation of the applicant should be considered as the only justification for the different treatment in order for this to be considered discrimination under the Convention. Paragraph 93 is, therefore, clearly in contrast with the position of the IACtHR in Atala Riffo. In conclusion, the IACtHR referenced the ECtHR with the likely intent of

\footnotetext{
93 ibid.

94 Atala Riffo (n 85) 94.

95 ibid 93.
} 
strengthening the convergence of the two courts' case-law ${ }^{96}$ but it ended up determining a situation of fragmentation.

In light of the above, the IACtHR concluded that Chile did violate the principle of non-discrimination based on the sexual orientation of Mrs Atala Riffo. ${ }^{97}$

In addition, the IACtHR ruled that such a decision amounted to a violation of the right to privacy and family life, setting a very broad and progressive understanding of 'family', going beyond the traditional and conservative concept, requiring the state to develop and strengthen, 'in the broadest possible terms', the family unit. ${ }^{98}$

A very similar position, fully condemning discrimination based on sexual orientation, was held by the Court in its recent case, Angel Duque v Colombia. The case concerned the denial of the survival pension to Mr Duque after the death of his same-sex partner. The IACtHR, perfectly in line with the HRC, held that the state's internal regulations providing the possibility to obtain a survivor's pension only to heterosexual couples, without an objective and reasonable justification as to the reason for the differential treatment, was discriminatory and contrary to the right to equality. ${ }^{99}$ The IACtHR acknowledged the fact that Colombia was pursuing the aim of protecting the family as a fundamental basis of society. However, while legitimate in theory, the difference in treatment could not be considered proper, as the concept of family cited by the state is limited and stereotyped, arbitrarily excluding different types of families such as those formed by same-sex partners. ${ }^{100}$ In addition, the IACtHR held that a lack of

\footnotetext{
${ }^{96}$ Alvaro Paúl, 'Examining Atala-Riffo and Daughters v. Chile, the First Inter-American Case on Sexual Orientation, and Some of Its Implications' (2014) 7 Inter-American and European Human Rights Journal 54.

${ }^{97}$ Atala Riffo (n 85) 96-110.

98 ibid $169-172$

${ }^{99}$ Duque (n 86) 99 and 124.

${ }^{100}$ ibid 160.
} 
consensus among its member states, the so-called regional consensus, about the rights of sexual minorities does not prevent it from deciding the issue. ${ }^{101}$

\section{A Fragile Convergence: the Threat of Fragmentation}

The above analysis shows that, while on the surface there is a general convergence in the approach to sexual orientation issues in the case-law of regional courts and the HRC, a deeper analysis reveals that a phenomenon of fragmentation is actually taking place and can increase due to a number of elements of fragility.

Recalling the definition of judicial fragmentation as the phenomenon arising when two courts seized of the same (or similar) matter issue contrasting judgments, ${ }^{102}$ six remarks can be made, identifying some cases where fragmentation is already affecting sexual orientation rights at the international level and other elements that could further undermine convergence and similarly lead to fragmentation.

First, the comparison between the notion of discrimination based on sexual orientation in the Inter-American and the European Court reveals a deep difference that can be considered an embryonal form of judicial fragmentation. On the one hand, the IACtHR ruled that for a violation of article 1 of the ACHR it is not necessary that the decision is 'fundamentally and solely' based on the person's sexual orientation, as it would be enough to prove that the sexual orientation of the applicant has been taken somehow, implicitly or explicitly, into account. On the other hand, the ECtHR, in both Salguiero da Mouta and E.B., has reiterated the need to assess that the different treatment was 'solely' based on the sexual orientation of the applicant and that the latter was the 'decisive element' of the deliberation in order to amount to a violation of article 14 of the

\footnotetext{
101 ibid 123.

${ }^{102}$ Webb (n 4); Martti Koskenniemi and Päivi Leino, 'Fragmentation of International Law? Postmodern Anxieties' (2002) 15 Leiden Journal of International Law 553.
} 
ECHR. ${ }^{103}$ This divergence, that in the practice has not yet produced any contrasting judgment, shows a different understanding of the notion and approach to the issue. According to the classical definition of judicial fragmentation, this difference in reasoning does not trigger fragmentation in the sense that it did not lead to contrasting judicial application of convention rights and, subsequently, contrasting outcomes. However, the two notions depart so much from each other that we can conclude that judicial fragmentation is partially affecting the interpretation of the prohibition of discrimination.

A perusal of the previous case-law of the IACtHR on prohibition of discrimination shows that Atala Riffo is the first and only case where the Court adopted such a definition of different treatment for the sake of the application of article 1 of the ACHR. This finding leaves a veil of uncertainty about the actual approach of the IACtHR on the matter. On the one hand, it could be argued that this peculiar position is adopted only in cases of sexual orientation involving controversial domestic judgments and IACtHR did not have the possibility to apply it in further cases because it no other similar cases were brought before it. However, in Angel Duque v Colombia no mention can be found of this new approach toward discrimination. On the other hand, this innovative stance on the definition of discrimination could be the result of an attempt by the IACtHR to explore alternative interpretation paths. Yet, it is still an embryonal stage that does not allow further speculation. Moreover, it should be acknowledged that the ECtHR has elsewhere stated that it would review indirect discrimination as rigorously as it reviews direct discrimination, ${ }^{104}$ thus stepping closer to the IACtHR's approach. However, these cases

\footnotetext{
${ }^{103} E . B$ (n 62), 93.
}

${ }^{104}$ D.H. and Others $v$ Czech Republic, Application No. 57325/00 (ECtHR, 13 November 2007) Hoogendijk $v$ the Netherlands, Application No. 58641/00 (ECtHR, 6 January 2015) 
do not concern sexual orientation and they do not allow us to make any conclusive inferences.

Second, the case-law of regional bodies and of the HRC shows that the ground of discrimination under which 'sexual orientation' should fall is still debated. Sometimes falling under 'sex', some others under the very broad 'other status' or 'any status', this ambiguity may potentially generates misunderstanding in the nature of the discrimination.

Third, the case-law on the right to marry reveals that while there is a strong convergence on the absence of a right to marry for same-sex couple, there is still lot of confusion on whether should be considered discriminatory a different treatment between a married heterosexual couple and a same-sex couple unable to marry. The ECtHR seems firm in excluding such a possibility, ${ }^{105}$ while the HRC, in its General Comments and in the concurring opinion in Joslin v New Zealand, leaves a door open to it. ${ }^{106}$

Fourth, the concept of 'family unit' as including same-sex couples in a de facto relationship, even when the right to marry is not involved, is still not fully established. Indeed, the concurring opinion in $X . v$ Colombia before the $\mathrm{HRC}^{107}$ and the close vote in $X$ and Others $v$ Austria before the ECtHR ${ }^{108}$ show that the progressive understanding of the notion of 'family' is highly debated and often questioned even when it is not related to the right to marry or to adopt.

Fifth, the ECtHR and the IACtHR adopted a different approach to the so-called 'regional consensus'. On the one hand, for the ECtHR the existence of a regional consensus, especially on sensitive matters like marriage and adoption, is a key element

\footnotetext{
105 Schalk and Kopf (n 48), Chapin and Charpentier (n 51), Gas and Dubois (n 64).

106 Joslin (n 28).

${ }^{107} \mathrm{X}$ v Colombia (n 33).

${ }^{108} \mathrm{X}$ and Others (n 67).
} 
for deciding in favour of the applicant. ${ }^{109}$ On the other hand, the IACtHR has openly stated that the absence of a regional consensus among its member states does not prevent the court from interpreting the Convention in a certain way. ${ }^{110}$ This divergence of behaviour is strictly linked to the use by the ECtHR of the margin of appreciation. ${ }^{111}$ Indeed, when the ECtHR found no regional consensus on a matter, it usually granted a wide margin of appreciation to its member states. ${ }^{112}$ It repeatedly held that, where a difference in treatment is based on sex or sexual orientation, the state's margin of appreciation is narrow $^{113}$ and differences that are based solely on considerations of sexual orientation are unacceptable under the Convention ${ }^{114}$ and no margin of appreciation should be granted. However, in the cases concerning the right to marry for same-sex couples, the ECtHR did grant a very wide margin of appreciation to the states. The opposite attitude of the IACtHR, ignoring the regional consensus on such matter and never recurring to the margin of appreciation, can be considered as a further element of weakness of the current convergence of case-law. Indeed, the IACtHR, when seized of a matter like marriage for same-sex couples with no regional consensus on its regulation, could freely rule in a very progressive way, thus contrasting with the position of the ECtHR. ${ }^{115}$

As for the two other bodies, the element of consensus has not been invoked yet in cases on sexual orientation. For the HRC is very challenging to assess the existence of a

\footnotetext{
109 Aldeguer Tomas (n 72) and Schalk Kopf (n 48).

${ }^{110}$ Duque (n 86).

${ }^{111}$ Frans Viljoen, (n 9)

${ }^{112}$ Dean Spielmann, 'Allowing the Right Margin: The European Court of Human Rights and the National Margin of Appreciation Doctrine: Waiver or Subsidiarity of European Review? (20112012) 14 Cambridge Yearbook of European Legal Studies 381 and Andrew Legg, The Margin of Appreciation in International Human Rights Law: Deference and Proportionality (OUP, 2012). ${ }_{113}$ Kozak (n 75) 92 and Karner (n 75) 41.

114 E.B.(n 62) 93-96, and Salgueiro da Silva Mouta (n 44) 36.

115 Paúl; GL Neuman, 'Import, Export, and Regional Consent in the Inter-American Court of Human Rights' (2008) 19 European Journal of International Law 101.
} 
consensus of its member states in such a sensitive issues, being 116 the countries that accepted the jurisdiction of the committee over individual complaints. Moreover, in Toonen, the Committee held that 'moral justification cannot be considered as a matter exclusively for domestic concern' as such an approach would open the door to removing the Committee's supervisory role'. ${ }^{116}$ As for the African Commission, the role of consensus in its ruling has been very limited so far. ${ }^{117}$ While in one case it stated that 'the African Charter should be interpreted in a culturally sensitive way, taking into full account the differing legal traditions of Africa and finding expression through the laws of each country', ${ }^{118}$ the Commission never followed this approach and even when it granted a margin of appreciation, it did so without assessing the existence or the lack of a regional consensus. ${ }^{119}$

Lastly, the prohibition of discrimination based on sexual orientation within the African system is still a debated matter. All regional systems and the UN HRC provide the possibility for their Commissions and Courts to offer their good service to the parties with the aim of reaching a 'friendly settlement'. ${ }^{120}$ The successful attempt of the African Commission to induce the applicant to withdraw his complaint in Courson v Zimbabwe is an extreme example of it. ${ }^{121}$ In view of the explicit consideration of the Commission's rapporteur for the case, we can conclude that this was definitely an effective way for avoiding a judicial fragmentation that would have otherwise arisen. As previously

${ }^{116}$ Toonen v Australia (n 24), 8.6.

${ }^{117}$ Magnus Killander, 'Interpreting Regional Human Rights Treaties' (2010) 7 SUR - International Journal on Human Rights 144.

${ }^{118}$ Constitutional Rights Project and Another v Nigeria, 1999, 26.

${ }^{119}$ Prince v South Africa, 2004.

${ }^{120}$ ECHR art 39, ACHR art 48(f), ICCPR art 41(e) and Information Sheet No. 3 of the African Commission on Human and People's Rights, available at http://www.achpr.org/files/pages/communications/procedure/achpr_communication_procedure_ eng.pdf, last accessed $3^{\text {rd }}$ September 2016.

${ }^{121}$ Courson (n 78). 
observed, if the Commission had to issue a view on that, it would have been most probably contrasting with the existent regional and international case-law. Given the attitude so far of the African Commission on sexual orientation matters, it is not hard to imagine that a strengthening of the African system, together with a rise in the number of cases related to sexual orientation brought to the attention of the Commission, may actually increase the chances of triggering judicial fragmentation.

\section{Conclusion}

Discrimination based on sexual orientation is generally considered a matter where, regardless of the important cultural, social, religious and political concerns, regional and international human rights bodies have reached a substantial convergence in their judicial application. The present study demonstrated that such convergence is more apparent than genuine and while it is true on the surface, a deeper analysis of the reasoning of the different bodies reveals that there are signs of current and potential fragmentation.

As previously discussed, some of the key aspects related to discrimination based on sexual orientation and related rights like the right to marry or to have a family are still far from being settled and agreed upon. The difference in the notion of discrimination between the ECtHR and the IACtHR is certainly crucial and reveals a deep divergence in the approach toward the issue and could potentially lead to fragmentation in future discrimination cases, even beyond sexual orientation issues. In addition, the confusion on the interpretation of some notions, such as 'family', and on the approach to adopt in different circumstances, as in cases of adoption and social protection, are definitely potential threats to the existing fragile convergence.

One of the main reasons behind the lack of a general and widespread fragmentation on the matter is the very low number of complaints brought before the regional bodies and the HRC. Especially in the case of the HRC, IACtHR, ACommHPR 
and ACtHPR, the absence of applications on specific issues prevented them from adequately discussing the different matters and interpreting their respective conventions. Indeed, the impossibility of testing the approach of the different bodies on every specific matter is the biggest obstacle to a comprehensive and ultimate analysis on convergence and fragmentation.

In conclusion, the current overall convergence on sexual orientation rights should be welcomed as a confirmation of the universality of rights, but attention should be paid for future development which may lead to fragmentation, with the hope that subsequent harmonisation will not mean the affirmation of a lower standard of protection. 